\title{
SITUATED LEARNING FOR STUDYING LITERATURE IN THE SCHOOL FOR VISUALLY IMPAIRED STUDENTS
}

\section{BRUGMAN BOEYNAEMS}

Research Institute for Learning and Education

Email: boeynaems@rile.org

This paper presents an investigation carried out within the school for visually impaired students in Penang, Malaysia, for studying literature. The aim of the research is to discover which learning processes generate integration opportunities for the visually impaired students. We conducted the research through a qualitative approach which was based on the methodological plurality using case studies, ethnography and biographical-narrative research. For data collection, we used biographical-narrative interviews, discussion groups and field diaries. For the theoretical bases, we emphasized the concepts of situated learning which are proposed by Lave and Wenger. We presented the results of the research which are expressed in the story of the students' learning.

\section{KEYWORDS:}

Visual impairment, situated learning, learning context, special education.

\section{APA CITATION:}

Boeynaems, B. (2020). Situated learning for studying literature in the school for visually impaired students. Journal of Learning Landscape, 10(2), 11-38.

\section{DISCLOSURE STATEMENT}

No potential conflict of interest was reported by the authors.

\section{REFERENCES}

Banovic N., Franz R. L., Truong K. N., Mankoff J. \& Dey A. K. Uncovering information needs for independent spatial learning for users who are visually impaired. In ACM SIGACCESS (2013), 24. 
Brock A. M., Truillet P., Oriola B., Picard D. \& Jouffrais C. Interactivity improves usability of geographic maps for visually impaired people. Human-Computer Interaction 30, 2 (2015), 156-194.

Cass H. Visual Impairment and Autism: Current Questions and Future Research. Autism 2, 2 (1998), 117-138.

Dale N. \& Salt A. Social identity, autism and visual impairment (VI) in the early years. British Journal of Visual Impairment 26, 2 (2008), 135-146.

Datta P. Self-concept and vision impairment: A review. British Journal of Visual Impairment 32, 3 (2014), 200-210.

Diamond K. E. The development of social competence in children with disabilities. In Blackwell handbook of childhood social development, P. K. Smith C. H. Hart, Ed., Blackwell handbooks of developmental psychology. Blackwell Publishing, 2002, 572-587.

Dramas F., Macé M., Katz B. F. \& Jouffrais C. Object Localization System for the Blind: Designing a User-Centered Auditory Interface. In CSUN Conference (2010).

Holt R., Moore A.-M. \& Beckett A. Together Through Play: Facilitating Meaningful Play for Disabled \& Non-Disabled Children through Participatory Design. In Inclusive Designing: Joining Usability, Accessibility, and Inclusion, Springer-Verlag (2014).

Kinoe Y.\& Noguchi A. Qualitative Study for the Design of Assistive Technologies for Improving Quality of Life of Visually Impaired. In Human Interface and the Management of Information. Information and Knowledge in Applications and Services, S. Yamamoto, Ed., vol. 8522 of Lecture Notes in Computer Science. Springer International Publishing, 2014, 602-613.

McGaha C. G. \& Farran D. C. Interactions in an inclusive classroom: The effects of visual status and setting. Journal of visual Impairment and Blindness 95, 2 (2001), 80-94.

Melie, Steina, et al. "Foreign language training for visually impaired students in South East Asian countries." (2020).

Nanda, Deri Sis. "Fostering the Use of Drama for English Language Learners in the Efl Classroom." International Conference on Education and Language (ICEL). 2016.

Nanda, Deri S., and Susanto Susanto. "THE EMERGENCE OF CYBER LITERATURE: A CHALLENGE TO TEACH LITERATURE FROM TEXT TO HYPERTEXT." EdArXiv, 21 Jan. 2020. Web. 
Pietrzak T., Martin B., Pecci I., Saarinen R., Raisamo R. \& Jarvi J. The micole architecture: Multimodal support for inclusion of visually impaired children. In ICMI 2007 (2007), 193-200.

Susanto, Susanto. "A CASE STUDY OF PROSODIC PHRASAL GROUPING AND INTONATIONAL PROMINENCE IN LANGUAGE ACQUISITION." English Review: Journal of English Education 4.2 (2016): 289-295.

Susanto, Susanto, and Deri Sis Nanda. "TEACHING AND LEARNING ENGLISH FOR VISUALLY IMPAIRED STUDENTS: AN ETHNOGRAPHIC CASE STUDY." English Review: Journal of English Education 7.1 (2018): 83-92.

Thompson, R. G. Extraordinary bodies: Figuring physical disability in American culture and literature. New York, NY: Columbia University Press, 1997.

World Health Organization, visual disturbances and blindness (H53-H54), 2015. Adiguzel T., Capraro R. M. \& Willson V. L. An Examination of Teacher Acceptance of Handheld Computers. International Journal of Special Education 26, 3 (2011), 12-27. 